\title{
Cyclic hyperammoniemic encephalopathy and epileptiform triphasic waves: problems in differential diagnosis with nonconvulsive status epilepticus
}

\author{
Alberto Primavera · Daniela Audenino
}

Received: 18 July 2008/Accepted: 20 January 2009/Published online: 24 February 2009

(C) Springer-Verlag 2009

Dear Editor,

We would like to make three points about the case of cycling hyperammoniemic encephalopathy in an old women with a past history of uterosigmidostomy discussed by Tremolizzo et al. [1].

The first point concerns diagnosis of nonconvulsive status epilepticus (NCSE). De novo NCSE is not infrequent in elderly patients but as emphasized by Walker et al. [2] the diagnosis is often made with significant delay because the clinical picture of NCSE is difficult to differentiate from that of a metabolic encephalopathy unless an EEG is obtained. NCSE is under-recognized in clinical practice and a high level of suspicion is essential. There is the low awareness among physicians of the diagnostic utility of emergent EEG [3].

The second point is that a large spectrum of EEG ictal abnormalities may be observed in NCSE, including triphasic wave (TWs) with epileptiform characteristics. In particular, Kaplan (1999) [4] stressed that "when TWs appear with a frequency exceeding $1 / \mathrm{s}$ the distinction between encephalopathy and NCSE is difficult" and reported an EEG tracing showing flurries of triphasic waves (TWs) in a waxing and waning pattern in a patient with hyperammonemia. These EEG abnormalities are very

\footnotetext{
A. Primavera $(\bowtie)$

Department of Neuroscience, Ophthalmology and Genetics, University of Genova, Via De Toni, 5, Genoa, Italy

e-mail: aprimavera@neurologia.unige.it

D. Audenino

S.O.C Neurologia, E.O Ospedali Galliera, Mura Cappuccine, 14, Genoa, Italy

e-mail: daniela.audenino@galliera.it
}

similar to EEG pattern reported by Tremolizzo et al. Differential diagnosis between TWs of metabolic encephalopathy versus spike wave stupor was previously discussed [4]. In these cases it is mandatory to search a risk factor of mental status impairment (toxic-metabolic encephalopathy, as electrolytic imbalance, drugs toxicity, renal or liver failure, etc.) [5].

Finally, the immediate administration of benzodiazepines (lorazepam, diazepam) is the unequivocal first step for the treatment of NCSE. Bolus administration of intravenous valproic acid or phenytoin may be tried beyond benzodiazepines, but phenytoin should be used only in focal NCSE as it may cause aggravation of absence status [5].

\section{References}

1. Tremolizzo L, Galbussera A, Frigo M, Apale P, Capra M, Appollonio I, Ferrarese C (2008) Rapidly cycling encephalopathy from an almost forgotten entity. Neurol Sci 29:125-126

2. Walker M, Cross H, Smith S, Young C, Aicardi J, Appleton R, Aylett S, Besag F, Cock H, DeLorenzo R, Drislane F, Duncan J, Ferrie C, Fujikawa D, Gray W, Kaplan P, Koutroumanidis M, O'Regan M, Plouin P, Sander J, Scott R, Shorvon S, Treiman D, Wasterlain C, Wieshmann U (2005) Nonconvulsive status epilepticus: Epilepsy Research Foundation workshop reports. Epileptic Disord 7:253-296

3. Primavera A, Audenino D, Cocito L (2004) Emergent EEG: indications and diagnostic yield. Neurology 62:1029

4. Kaplan PW (1999) Assessing the outcomes in patients with nonconvulsive status epilepticus:nonconvulsive status epilepticus is underdiagnosed, potentially overtreated, and confounded by comorbidity. J Clin Neurophysiol 16:341-352

5. Van Rijckevorsel K, Boon P, Hauman H, Legros B, Ossemann M, Sadzot B, Schmedding E, van Zandijcke M (2006) Standards of care for non-convulsive status epilepticus: Belgian consensus recommendations. Acta Neurol Belg 106:117-124 